\title{
Türkiye'de Yaşlılık Algısı: Yaşı Ayrıcalığı ve Ayrımcılığı Üzerine Bir İnceleme
}

\author{
Perception of Aging in Turkey: A Study on Elder Privilege and Discrimination
}

\section{Şerif ESENDEMIR ${ }^{1}$}

\author{
Makale Bilgisi/ Article Information \\ Geliş/ Received: 18.10 .2021 \\ Kabul/ Accepted: 16.12.2021 \\ Yayın/ Published: 31.12.2021
}

Araştırma makalesi/ Research article Doi: 10.47155/mamusbbd.1011701

\author{
Kaynakça Bilgisi/ Citation Information \\ Esendemir, E. (2021). Türkiye'de yaşlılık algısı: Yaşlı ayrıcalığı ve \\ ayrımcılığ \\ Beşerî Bilimler Dergisi, 4(2), 74-86. \\ https://doi.org/10.47155/mamusbbd.1011701 \\ Esendemir, Ş. (2021). Perception of aging in Turkey: A study on elder \\ privilege and discrimination. Maarif Mektepleri International Journal of \\ Social and Humanistic Sciences, 4(2), 74-86. \\ https://doi.org/10.47155/mamusbbd.1011701
}

Öz

Yaşlı ayrıcalığı ve ayrımcılığı, toplumsal düzeyde her alanda kültüre içkin olarak kullanılan dilde, karikatürlerde, medyada ve reklamlarda kendisini bariz bir şekilde gösteren iki olgudur. Öyle ki, yaşlı ayrımcılığında, yaşlının, gelenekle özdeşleştirilip modern olmadığı yönünde söz konusu mecralarda sunulması, modern Batı toplumlarında bile göze çarpmaktadır, çünkü kendilerini modern olarak tanımlayan Batı toplumlarının gençliği ön plana çıkarmaları yaşlılığın olumsuz olarak etiketlenmesi sonucunu doğurmuştur. Muhafazakâr olarak tanımlanan doğu toplumlarında ise kolektif cemiyet ruhu ve geniş aile yapısı bulunduğundan, dayanışma örüntüleri hâlâ devam etmektedir. Dolayısıyla, bu durum yaşlı ayrımcılı̆̆ının doğu toplumlarında sistematik hale gelmesini önlediği söylenebilir. Ancak yine de yaşlı ayrıcalığının da eş zamanlı olarak yaşanmasını engelleyemediği görülmektedir. Türkiye, doğu ve batı arasında bir köprü işlevi gördüğü için yaşlı ayrıcalığı ve ayrımcılığı konusunda da hibrit bir vaziyet arz etmektedir. İşte bu çalışma, Türkiye'de yaşlılık algısı bağlamında yaş ayrıcalığı ve ayrımcılığının medyadaki yansıması nasıldır? sorusundan yola çıkılarak Türkiye'nin bu özgün/özgül durumunun ortaya çıkarılması amacıyla yapılmıştır. Bu amaçtan yola çıkılarak yapılan incelemenin sonuçları, medya özelinde Türkiye'de yaşlı ayrıcalığı ile ayrımcılığının eş zamanlı olarak gözlendiğini ortaya koymuştur.

Anahtar Kelimeler: Yaşlı Ayrıcalı̆̆ı, Yaşlı Ayrımcıllı̆̆, Gelenek, Modernleşme, Medya.

\section{Abstract}

The privilege and discrimination of the elderly are two phenomenon manifest themselves in the language, cartoons, media and advertisements that are used in every field at the social level. So much so that, in age discrimination, for example, the fact that the elderly are identified with tradition and presented in such media that they are not

${ }^{1}$ Yıldız Teknik Üniversitesi, Fen-Edebiyat Fakültesi, İnsan ve Toplum Bilimleri Bölümü, Doç. Dr

圈

(iD) $0000-0002-7862-5540$ 
modern stands out even in modern western societies, because of the fact that Western societies, which define themselves as modern, emphasize youth, has resulted in the negative labelling of old age. In the eastern societies, which are determined to be conservative, the patterns of solidarity continue, as there is a spirit of collective community and extended family structure. Therefore, this situation not only prevents ageism from becoming systematic in eastern societies but also leads to the simultaneous experience of elder privilege. Since Turkey has a bridging role between east and west, it also presents a hybrid situation regarding of elder privilege and discrimination. Here in this study, "How is the reflection of age privilege and discrimination in the media in the context of old age perception in Turkey?" is main question. This study was conducted to reveal this unique situation of Turkey based on this question. The findings of the study, which was carried out based on this purpose, revealed that the privilege and discrimination of the elderly work simultaneously in Turkey, especially in the media.

Keywords: Age Privilege, Ageism, Tradition, Modernization, Media.

\section{Giriş}

Demografik dönüşüm artık Türkiye'nin de bir gerçeğidir. Genç nüfus günümüzde daha fazla olmasına rağmen tıptaki gelişmeler, ortalama ömrün uzaması, doğum ve ölüm oranlarının düşmesiyle birlikte yaşlı nüfus tabakası her geçen gün biraz daha büyümektedir. Yaşlı nüfusun artması, yoksulluk, yalnızlık ve engellilik gibi sorunlarının ve teknoloji desteği ve boş zamanı içeren firsatlarının da büyümesi anlamına gelmektedir. Sorunları bağlamında COVID-19 Pandemi Süreci'nde bile diğer yaş gruplarına göre kronik hastalıklarından ve bağışıklık sistemlerinin zayıflığından kaynaklı vefat sayıları artan yaşlılara yönelik sosyal medyaya da yansıyan birçok olumsuz olay yaşanmıştır. Dolayısıyla yaşlılara yönelik bu olumsuz yaklaşımların temelinde nelerin olduğu toplum tarafından sorgulanmaya başlanmıştır? Böylece Türkiye'de bir taraftan yaşlı büyüklere yaşlı ayrıcalığı bağlamında hürmet gösterilirken öbür taraftan da yaşlı ayrımcılığı kapsamında "şaka/mizah" yoluyla da olsa aşağılanmaya başlanmaları toplum için büyük bir merak konusu olmuştur. İşte bu ilgi ve merak doğrultusunda toplumu bilimsel olarak aydınlatmak için araştırma sorusu "Türkiye'de yaşlılık algısı bağlamında yaş ayrıcalığ 1 ve ayrımcılığının medyadaki yansıması nasıldır?" şeklinde geliştirilerek yaşlılara yönelik ayrıcalık ve ayrımcılığının dijital ve yazılı medyadaki temsili yetmiş kişiye de sorularak internet ve kütüphane kaynaklı tarama metoduyla incelenmiştir.

Yaşlı ayrıcalığı ve ayrımcılığını, ana hatlarıyla bireysel, kültürel ve yapısal olmak üzere üç farklı düzeyle açıklamak mümkündür. Bireysel düzey, bireyin yaşlıya bakış açısının, içinde büyüdüğü ve sosyalleştiği toplumda ne kadar belirleyici olduğu yönündedir. Kültürel düzey, yaşlı ayrıcalığının ve ayrımcılığının kültürün yaşlılıkla ilgili nasıl bir dile sahip olduğu ve farklı ideolojik aygıtlarla bunu nasıl kullandığıyla alakalıdır. Yapısal düzey, kurumların yaşlılara yönelik sürdürülebilir politikalar geliştirip geliştirememesiyle ve verdikleri hizmet kalitesini artırıp artıramamalarıyla ilişkilidir (Butler, 1975). Bu inceleme, yaşlı ayrıcalığı ve ayrımcılığının bireysel ve yapısal düzeylerine değinmesine rağmen, sadece kültürel düzeyine odaklanmıştır, çünkü medya dilini de kapsayan kültürel düzey, yaşlı ayrıcalığı ve ayrımcılığının açık bir şekilde yaşandığı ve teşhir edildiği alandır.

Yapılan incelemenin detaylarına geçemeden önce yaşlı ayrıcalığı ve yaşlı ayrımcılığı tanımı yapılarak çalışmada bunlardan ne kastedildiği ortaya konulmalıdır. Öncelikle yaşlı ayrıcalığından başlanırsa, yaşlı ayrıcalığı, dini ve kültürel değerlerden yola çıkılarak bilge ve tecrübeli görülen yaşlı kişiye saygı gösterilmesi ve dolayısıyla onun toplumda öncelikli/ayrıcalıklı bir yerde konumlandırılmasıdır. Yaşlı ayrımcılığı ise, bir insana karşı genelde yaşı nedeniyle gösterilen farklı tavırlar ve geliştirilen önyargılar şeklinde tanımlanmaktadır (Akdemir, Çınar ve Görgülü, 2007). Gerontoglar, genel itibariyle, yaşlilara yönelik ayrımcılığın toplumda büyük bir sorun teşkil ettiği noktasında aynı fikirdedirler 
(Palmore, 1999). Ancak bazı gerontologlar ve geriatrisyenler bile kullandıkları dil ve üslup nedeniyle dolaylı olarak bu ayrımcılığın bir aracı olabilmektedirler.

Yaşlı ayrımcılığı, yaşlıyı ötekileştirdiği için ırkçılık benzeri bir forma bürünmüştür. Bilindiği üzere cinsiyet ayrımcılığı insanın biyolojik farklılıkları üzerinden erkek egemenliğini kurarken 1rk ayrımcılığı da bir ırkı diğerinden üstün görmeye dayanmaktadır (Görgün Baran, 2012). Bunlara benzer şekilde "genç" kimliği ve "yaşlı" kimliği birbirlerine referansla kurulmaya başlanmışlardır. Böyle bir karşılaştırma bile, yaşlıya karşı birtakım ayırımcı eylemelere yol açıp yaşlıların kenara çekilip yalnızlaşmalarına yol açmaktadır. Aktif bireyler olarak kendilerine özellikle gönüllülük çalışmalarında bir meşguliyet ihdas eden yaşlıların bile medya aygıtlarında "mizah" adı altında dolaylı da olsa aşağılanmaları çok ilginçtir. Bu nedenledir ki bu çalışmada, yaşlı ayrıcalığından daha çok yaşlıların hareket alanını daraltarak onları toplumun dışına itmeye çalışan yaşlı ayrımcılığının içerik analizi yapılarak konvansiyonel ve dijital medyadaki yansıması üzerinde durulmuştur.

\section{Kuramsal ve Kavramsal Çerçeve}

Sosyal bilimciler, sosyal değişimin yaşlılar üzerindeki etkisini anlamak için genelde yaşlılığa gelenek ve modernlik bağlamında bakmaktadırlar. Modernleşmenin her alanda etkileri yaşandığı gibi yaşlıları da etkilemektedir. $\mathrm{Bu}$ nedenle, yaşlılık bilimi olan gerontolojide geliştirilen modernleşme kuramında yaşlıları her açıdan etkileyen büyük çaplı değişimler ele alınmaktadır. Dahası, toplumların, özellikle, sosyal ve teknolojik açıdan modernleşmesinin yaşlılar üzerinde nasıl sosyo-kültürel etkiler bıraktığı açıklanmaktadır.

Modernleşme kuramı sanayi toplumu öncesi yaşlılar için bir altın çağ olduğu varsayımına dayanmaktadır. Bu kurama göre sanayi toplumu öncesinde yaşlılar, bilgelikleri nedeniyle saygı duyulan kişiler olmuşlardır (Street, 2007, s. 154). Türk toplumunda da bu bağlamda yaşlı ayrıcalığı din ve kültür öğeleri tarafından desteklenmiştir. Örneğin, Türk din, adet ve geleneğinde yaşlanan ana-baba hakkına riayet etmek Allah'a itaat etmekten sonraki ilk sirada gelmektedir. Toplumdaki yaşlı anasına bakan Veysel Karani menkıbesi bunun sözde kalmayıp amele/pratiğe döküldüğünün delilidir (Ekinci, 2012). Mesela, Fatih Sultan Mehmet Han'in bir bilge olarak büyük bir saygı gösterip danıştığı Akşemsettin ismindeki "ak" yaşlı bilge sıfatıdır. Dede Korkut'taki "dede" ve toplumda yaygın olarak kullanılan "pir" ibareleri hep yaşlı bilge olma sıfatlarıdırlar. Bu nedenledir ki günümüzde bile Türk toplumunda yaşliya saygi/hürmet bağlamında bu yaşlı ayrıcalığı bir yandan devam etmektedir (TDK, 2011).

Öte yandan, modernleşme, yaşlının güçlü olduğu aile merkezli tarım ve zanaat üretiminden sanayi üretimine geçişi ifade ettiği için kuramı da yaşlıların bu geçişle birlikte statülerini kaybettikleri iddiasındadır (Cowgill ve Holmes, 1972). Dahası, söz konusu kuram, modernleşmeye bağlı olarak gelişen teknoloji, kentleşme ve eğitim düzeyinin yükselmesiyle birlikte bu statü kaybının hızlandığını varsaymaktadır (Cowgill, 1974). Bu iddialar birkaç konuda ele alınmaktadır. Birincisi, sağlık teknolojisi, yaşlıların ortalama ömürlerini uzatmaya yardımcı olsa da yaşın ilerlemesiyle birlikte ortaya çıkan birtakım olumsuz sağlık durumlarının iyileştirilmesine yönelik henüz bir çözüm bulamamıştır. İkincisi, sanayi teknolojisinin gelişmesi aletleri kullanmaya daha yatkın olan gençlerin istihdamını artırarak yaşlanan işçileri sistemin dışına itmiştir. Üçüncüsü, buna bağlı olarak gençlerin fabrikalarda çalışmak için kente göç etmeleri nedeniyle yaşlılarını kırda geride bırakmaları, geleneksel aile yapısını temelden sarsmıştır. Son olarak, modern eğitimin bütün yaş gruplarını kapsaması kuşaklararası eğitim farkını büyük oranda ortadan kaldırmıştır ve böylece yaşlıların eğitimde eskisi gibi görünür bir ayrıcalığı kalmamıştır (Street, 2007, s. 155). 
Modernleşme kuramında yaşlılık algısı topluma göre zaman içerisinde değişmektedir. Örneğin, Amerika'da, 1607-1770 tarihleri arasında kolonyal dönem şeklinde birinci evre olarak adlandırılan yaşı ayrıcalığının uygulamalarından biri olan yaşlı yönetimi/gerontokrasi vardır. Akabinde ise 1770-1820 yılları arasında devrim fikrinin yayılmasıyla birlikte yaşlı ayrıcalığı yerini ikinci evre olan yaşlı ayrımcılığına bırakmıştır. Böylece, ilk evrede yüceltilen ve övülen yaşlılar, ikinci evrede "moruk" ve "eski kafalı" gibi tabirlerle hor görülmeye başlanmışlardır (Fischer, 1978).

Modern evre olarak tanımlayabileceğimiz 1820-1970 y1lları arasındaki dönemde ise modernleşmenin de etkisiyle yaşlılık gençlikle kıyaslanmaya başlanmıştır. Bu kıyaslamada yaşlılık adeta gelenekle/eskiyle özdeşleştirilip gençlik ise modern/yeni olarak sunulmuştur. 1970 ve sonrasındaki evrede ise yaşlılık geriatri ve hatta yaşlılık bilimi gerontoloji tarafından bir "hastalık/sorun" olarak sunulup sosyal devletin müdahale etmesi gereken bir alan olarak tanımlanmıştır (Fischer, 1978). Gelinen noktada ise bunun da ötesine geçilerek artık beşinci evrede yaşlılık "yaşlılık sektörü" ve "tıbbi-sanayi kompleksi”" tarafindan ticari bir meta haline getirilmiştir (Estes, 2001).

Yaşlı ayrımcılığı son iki evrenin ürünüdür, çünkü bu kavram 1969'da ilk kez Amerika Ulusal Yaşlılık Enstitüsü Başkanı Gerontolog Robert Butler tarafından toplumdaki ihtiyarlara yönelik ayrımcılığı ve hatta önyargıyı tanımlamak için kullanılmıştır (Butler, 1975). Oysa Butler'den daha önce Sanayi Devrimi'nin akabinde, 19. yüzyılın sonlarında, işyerlerinde söz konusu ayrımcılığın 50 yaş ve üzeri kişilerin üretim talebini karşılamadıkları bahanesiyle işten çıkarılmaları şeklinde uygulandığı bilinmektedir (Baybora, 2010). Bu da yaşlı ayrımcılığının ilk önce iş hayatında ortaya çıktını göstermektedir. Sonrasında ise toplumun her alanına sirayet ederek ırk veya cinsiyet ayrımcılığı kadar tehlikeli bir boyut kazanmaya başlamıştır. Özellikle, genç kuşakların yaşlıları kendilerinden farklı görmeye ve kuşak çatışmasına varan pratikler geliştirmeye başlamaları tehlikenin boyutunu gözler önüne sermektedir. Örneğin, daha önce büyük saygı gören yaşlılar, yazılı ve görsel medyada 'mizah' yoluyla ayrımcılı̆̆a tabi tutulmaktadırlar. Bu da yaşlılığı istenmeyen bir durum haline getirmiştir (Cherry et al, 2013).

Toplumun yaşlılık algısı ve yaşlılığa karşı geliştirilen biyolojik bakış açısı, yaşlı ayrımcılığını besleyen sebeplerin başında gelmektedirler. Yaşlanma biyolojik olarak gerileme ve hastalıkların arttığı bir dönem olarak resmedilmektedir. Medya tarafından toplumdaki hızlı değişime temkinli yaklaşan yaşlıların yeniliklere uyum sağlamadıkları tezi savunularak onlara birer aktör değil, seyirci olmaları yönünde bir telkinde bulunulmaktadır. Özellikle, kültürel değerlerinden uzaklaşan toplumlar, yaşlıları beceriksiz görmekte ve dolayısıyla onları iş hayatından bir an önce uzaklaştırma eğilimindedirler. Oysa kültürel değerlerine bağlı toplumlar, yaşlılara hürmet mekanizmalarını çalıştırarak, onların tecrübelerinden faydalanma yoluna gitmekte, onları kıdemli vatandaşlar olarak bilge konumuna yerleştirmektedirler. Özellikle bazı doğu ülkelerinde erkek yaşlılar hayatın büyük bir bölümünü yaşamış ve anlamış oldukları için bilge olarak kabul edilmektedirler. Örneğin, Japonya' da bazı sağlık sorunları olan kadınların iş yükü azaltılmakta ve dolayısıyla gençler onlara hizmet etmeye özendirilmektedirler (Çilingiroğlu ve Demirel, 2004).

Burada yeri geldiği için yaşlı ayrımcılığının cinsiyet boyutuna da bakılabilir. Kadınlar erkeklere oranla daha fazla yaşlı ayrımcılığına maruz kalmaktadırlar (Marshall, 2007; Buz, 2015). Özellikle kamusal alana katılmalarının önündeki sınırlandırmalar/engellemeler kadın yaşlılarda erkeklere göre daha fazladır. Kadınlar erkelere göre fazla yaşadıkları için dul kalmakta ve yoksulluk gerçeğiyle daha erken tanışmaktadırlar. Bu ücretli bir işte çalışmadıkları için sosyal güvencesi olmayan yaşlı kadınlar için daha büyük bir risk teşkil etmektedir. $\mathrm{Ne}$ 
yazık ki ilerleyen yaşla birlikte gelen bu ve benzeri sorunlarla iyice zayıf konuma düşen yaşlı kadınlara yönelik ayrımcılık daha kolay uygulanmaktadır. Bu nedenledir ki gelişmiş ülkelerde bu sorunlarla baş etmek için kadınlara yönelik pozitif ayrımcılık politikaları geliştirilmiştir (Karasoy, 2021).

Türkiye'de yaşlılar, yaşlı ayrıcalığı kapsamında, tarih boyunca hürmette ve hizmette kusur gösterilmemeleri gereken bilgeler olarak kabul görmüşlerdir. Ancak küreselleşme, hızlı kentleşme ve kitle iletişim araçlarının yaygınlaşmasıyla birlikte değişmeye başlayan toplum yapısı, yaşlıya bakışı da olumsuz etkilemeye başlamıştır. Özellikle, ticari reklamlarda genç bedenin öne çıkarılması yaşı bedeni ikinci plana itmiştir. Özellikle dizilerde geliştirilen gelinkaynana tiplemeleri yaşl1lara yönelik geçinilmesi zor insan tipolojisini pekiştirmiştir.

Medyada gençler dinamik ve üretken bireyler olarak resmedilirken, yaşlılar tersine çalışma gücü azalmış ve artık topluma bir şey katmayacak pasif insanlar olarak sunulmaktadırlar. Aktif bir şekilde gösterilen yaşlılar bile oldukları gibi değil, kurgulandıkları gibi gösterilmektedirler. Örneğin, sağlık turizmi ve spor alanında yaşlıları da birer "müşteri" haline getirmek için "süper yaşlı" tiplemelerine başvurularak farklı maceralara ve tehlikeli sporlara yaşlılar da çekilmek istenmektedir. Başarılı yaşlanma, yaşlılığı geciktirme (anti-aging) ve aktif yaşlılık uygulamalarını suiistimal ederek yaşlı artık iddia edildiği gibi bir özne olarak değil, tersine bir nesne/müşteri konumuna getirilmektedir. Bu durumu yaşlı ayrımcılığının iki yüzü şeklinde tarif edebiliriz (Mchugh, 2003). Bir yüzü yaşlılık/yaşlılar hakkında negatif sterotipleri besleyip yaşlıların hayattan el etek çekmelerine yol açarken, öteki yüzü de "yaşlanmayı geciktirme", "hiç yaşlanmama" (Agelessness) gibi "iksirler"le biyolojik yıpranmayı hepten reddederek süper yaşlı profiliyle yaşlının olduğundan farklı gösterilmesine neden olmaktadır (Powell ve Chen, 2017).

Yaşlı ayrımcılığının ortaya çıkmasında etkili bazı faktörler, yaşlıların yaşlanmayla birlikte geliştirdikleri tutumlardan da kaynaklanabilmektedir. Yaşlılık bazen de ölümle eş anlamlı olarak algılanabilmektedir. Öyle ki ölüm korkusu yaşlının hayattan el etek çekerek başkasının görmezden gelmelerine yol açacak şekilde kendisini ihmal etmesine yol açabilmektedir. Bunu yapmakla yaşlı zaten ayrımcılık yapmaya teşne insanların kendilerine karşı ayrımcı pratikler geliştirilmesine adeta davetiye çıkarmaktadır. İleri yaşla birlikte gelen rahatsızlıkları nedeniyle de sürekli bakıma muhtaç insanlar olarak algılanıp bir yük olarak görülmektedirler. Sonuçta bir statü kaybı olarak görülen bu ve benzeri durumlar, yaşlı ayrımcılığının önünü açmaktadır.

Yaşlılık tanımları bile yaşlı ayrımcılığına adeta davetiye çıkarmaktadır. Bir başka deyişle, yaşlılıkla ilgili bir kısım tanımlarda bazı tabirlerle ileri yaşın etkileri ve özellikleri negatif bir şekilde hatırlatılmaktadır. Özellikle bunlardan "bunama", "hastalıklı olma", "güçsüzleşme", "yıpranmış olma", "fonksiyon görememe" gibi ifadelerle yaşlılığı kötü ve mümkünse kaçınılması gereken bir durum olarak resmetmektedirler (Özbolat, 2016; Kalınkara, 2011).

Özetlemek gerekirse, gerontologlar yaşlı ayrımcılığının oluşmasına esas teşkil eden dört etken üzerinde durmaktadır (Çilingiroğlu ve Demirel, 2004). Birinci etken ölümden duyulan korkudur. Ölüm yaşlılıkla eş anlamlı görüldüğü için yaşlının kendini hayattan adım adım geri çekmesine ve gençlerin de onları davrandıkları şekilde algılamalarına yol açmaktadır. İkinci etken kitle iletişim araçlarıyla birlikte bedensel güzelliğin ve cinselliğin ön plana çıkarılarak bu alanda gençlere nazaran yaşlıların yeterli ve piyasa için gerekli olmadıklarının ticari reklamlar aracılığıyla sunulmasıdır. Bu etken yaşlıların ekonomik verimlilik ve üreticilik anlamında gençlere nazaran artık geride kaldıkları yönündeki üçüncü etkeni de belirlemektedir. Sonuncu etken ise yaşlılarla ilgili yapılan çalışmaların çoğunun yaşlılara bakım hizmeti veren bakımevi 
ve huzurevi ile sağlık hizmeti veren hastane üçgeninde yürütülmeleri sebebiyle yaşliların sürekli bakıma muhtaçmış gibi gösterilmesi ve dolayısıyla buna yönelik bir toplumsal algının oluşmasıdır (Koçman, 2006).

Yaşlıların sadece bakıma muhtaç insanlar olarak algılanması kendi kendine yetebilen ve bağımsız bir şekilde kendi yaşamlarını sürdüren ihtiyarlara karşı büyük bir haksızlık olmaktadır. Çünkü yatağa bağlı yaşlıların oranı sadece \%8 civarındadır (Buz, 2015). Kurumsal bakıma başvuranlar da ancak \%1 oranındadır (Esendemir, 2015). Dolayısıyla, sadece bu istatistiklere bakacak olsak bile bütün yaşlıların kurumsal bakıma muhtaç gibi resmedilmesinin ne kadar büyük yanlış olduğu daha net görülecektir.

\section{Yöntem}

Çalışmanın metodu, araştırma tipi, ana olgu(lar), örneklem seçimi, veri toplama ve analizi içeriklerinden oluşan ATAOÖÇVTA kısaltması altında formüle edilmiştir. Araştırma tipi tarama modeline dayanan nitel bir özelliğe sahiptir. Araştırmada özellikle sosyal medya platformları (Twitter, Facebook ve Instagram) üzerinden dijital paylaşıma sokulan yaşlı temalı 37 karikatür incelenmiştir. Döküman taramasının yanısıra 70 kişiye de izledikleri TV'lerde (dizi, film ve reklam) ve okudukları kitaplarda (roman, hikâye ve masal) karşılaştıkları yaşlı ayrıcalığı ve ayrımcılığı temalarını belirtmeleri istenmiştir. Böylelikle bu iki ana olgu çerçevesinde araştırmacı tarafından 2018-2021 yılları arasında amaçlı örneklem çerçevesinde kavramlar haritası çıkarılmıştır. Bu kavramlar tematik analize tabi tutularak azaltma yoluyla iki ana tema altında toplanmıştır. Toplanan veriler doküman incelemesi tekniğine bağlı olarak tematik analize tabi tutulmuştur. Kısaca, doküman incelemesi tekniğine dayalı tematik analiz, temin edilen öne çıkan temaların incelenmesine dayanmaktadır (Sönmez ve Alacapınar, 2017, s. 108). Bu nedenle her türden tema değil, "Türkiye'de yaşlılık algısı bağlamında yaş ayrıcalığı ve ayrımcılığının medyadaki yansıması nasıldır?" araştırma sorusu için lazım olan temalarla çalışma sınırlandırılmıştır. Karikatür, dizi/film, reklam, roman/hikâye şeklinde sınıflandırılan alanlarda öne çıkan çok sayıdaki kategori yaşlı ayrıcalığı ve ayrımcılığı temaları altında toplanarak tematik analize tabi tutulmuştur. İncelemede güvenirlik, çalışmanın iç tutarlılığının sağlanması ve bu alanda uzman kişilerin onayının alınmasıyla elde edilirken, geçerlilik ise çalışmanın inandırıcılığı, kabullenirliği, aktarılabilirliği ve transfer edilebilirliği ile teminat altına alınmıştır.

\section{Bulgular ve Analiz}

Dijital ortamlarda (Twitter, Facebook ve Instagram) paylaşıma sokulan yaşlı içerikli 37 çizim taranmış ve doküman taramasının yanında 70 kişiye de izledikleri TV'lerde (dizi, film ve reklam) ve okudukları kitaplarda (roman, hikâye ve masal) dikkatlerini çeken yaşlı ayrıcalığı ve ayrıcalığı kategorilerini çıkarmaları istenmiştir. Böylece yaşlıya yönelik bakışı inceleyen bu inceleme, tarama ve soruşturma sonucunda, aşağıdaki Tablo 1 ve Tablo 2'de sunulduğu şekilde, temel kategoriler çıkarılmıştır. Sonrasında bütün bunlar yaşlı ayrıcalığı ve ayrımcılığı temaları altında toplanarak tematik analize tabi tutulmuşlardır.

\section{Bulgular}

Sınıf öğretmeni adaylarının yaşam alanları konusuna yönelik teknolojik pedagojik alan bilgilerinin belirlendiği araştırma bulguları; program bilgisi, öğrencilerin öğrenme 
güçlükleriyle ilgili bilgi, öğretimi etkiyecek diğer faktörler ortam (zaman-çevre), öğrenme strateji ve yöntem bilgisi ve değerlendirme bilgisi başlıkları altında sunulmuştur.

Tablo 1. Karikatürlerde yaşlı ayrımcılı̆̆ı kategorileri

\begin{tabular}{lll}
\hline Kategori & $\mathbf{N}$ & $\mathbf{\%}$ \\
\hline Hasta & 7 & $\% 18,9$ \\
\hline Çatışmacı & 6 & $\% 16,2$ \\
\hline Buyurgan & 6 & $\% 16,2$ \\
\hline Cinsel sapık & 4 & $\% 10,8$ \\
\hline Teknoloji okur-yazarı olmayan & 3 & $\% 8,1$ \\
\hline Yaşlandığını kabullenmeyen & 3 & $\% 5,4$ \\
\hline Saygı bekleyen & 2 & $\% 2,7$ \\
\hline İnatçı & 1 & $\% 2,7$ \\
\hline Hilekâr & 1 & $\% 2,7$ \\
\hline Eşini hor gören & 1 & $\% 2,7$ \\
\hline Cadı & 1 & $\% 2,7$ \\
\hline Paspal & 1 & $\% 100$ \\
\hline Süper yaşlı & 1 & \\
\hline Toplam & 37 & \\
\hline
\end{tabular}

Tablo 1'de görüldüğü üzere, taranan 37 karikatürde tamamen yaşlı ayrımcıllı̆ıının işlendiği görülmüştür. Yaşlı ayrıcalığı şeklinde değerlendirilebilir diye düşündügümüz "süper yaşlı" tiplemesinin de bir ironi görülmüştür. Gençler için bile tehlikeli olan sporu "Bakın yaşlı bile bu sporu rahatlıkla yapabiliyor" denilerek aslında dolaylı olarak gençler hedeflenmiştir. Bu nedenle, sözde yaşlı ayrıcalığı gibi görülen bu kategoriyi de yaşlı ayrımcılığ 1 teması altına alınmıştır. Görüldüğü üzere bir yazılı medya unsuru olan karikatürlerde tamamen yaşlı ayrımcılığ1 işlenmiştir. Bunun, "toplumsal bir eleştiri söylemi olarak mizah"ın karikatürlerde işlenmesi şeklinde olup olmadığına bakılması gerekmektedir. Mizah, Batı kültüründe "humour" olarak çıkışı itibariyle eleştireldir. Dahası, güldürürken sorgulama yapmayı da amaçlamaktadır ve hatta gelenek, görenek, töre tarafindan korunan gücü eleştirerek hür olma praksisini geliştirmeye de yardımcı olmaktadır (Avc1, 2003). Bütün bunlara rağmen yaşlıların olumlu gibi görünen "süper yaşlı" olarak etiketlenip karikatürize edilmeleri yaşlı ayrımcılığı "yaşçılık" olarak tercüme edilebilen "ageism"in bir sonucudur.

Tablo 1'deki yaşlı ayrımcılığı kategorisi altında toplanan karikatürlerde en çok işlenen yaşlının "hasta" olarak etiketlenmesi, artık sistematik bir hâl almış yaşçılığın dışavurumudur. $\mathrm{Bu}$ yaşçılık, yaşlının, özellikle yaşlılık endüstrisi ve tıp-sanayi kompleksi tarafından zaten "hasta/müşteri" olarak bilinçli şekilde gösterilmesinin sonuçlarından sadece birisidir. Öte yandan, yaşlılar "hasta" bireyler şeklinde resmedilerek artık onların özel yeteneklerinden ve tecrübelerinden faydalanılmasının önüne geçilmektedir. Bütün bunlar "dolaylı yaşlı ayrımcılığı" şeklinde de ortaya çıkarak yaşlının da bir yerden sonra bunları içselleştirmesine/benimsemesine yol açmaktadırlar.

Dolaylı yaşlı ayrımcılığı, iki farklı şekilde ifade edilmektedir. Birincisi, bilinçli yapılmasa bile gayri ihtiyari bilinçaltına işlemiş saiklerle yaşlıya farklı bir muamelede bulunma şeklinde izah edilebilir. İkincisi, tarafsız görünmekle birlikte belirli bir yaş grubunu kayırmak veya ötekileştirmek biçimde uygulamalarda ortaya çıkmaktadır. İş yerinde kariyer yükseltme eğitim programlarında yaşlılar yerine gençlere yer verilmesi buna bir örnektir. Çok yaygın olmazsa bile dolaylı yaşıı ayrımcılığı alanlarında bazen pozitif ayrımcılık da yapılmaktadır. Özellikle sosyal yardım konusunda yaşlılar gençlere nazaran daha ön plandadır. Ancak bu bile toplumda yaşlıların "muhtaç” oldukları önyargısının bir sonucudur. Dolaylı yaşlı ayrımcılığının tersi ise 
doğrudan yaşlı ayrımcılığıdır. Bu yasaların, sosyal politikaların ve uygulamalarının yaşlıları sırf yaşlı oldukları için dışlaması veya tercih etmesidir. İş ilanlarında belirli bir yaşın başvuru şartlarında belirtilmesi doğrudan yaşlı ayrımcılığının bir örneğidir. Dolayısıyla, doğrudan yaşlı ayrımcılığını tespit etmek dolaylı yaşlı ayrımcılığından çok daha kolay bir iştir (BandWinterstein, 2015).

Bulgularda en çok öne çıkan yaşlının "çatışmacı" olduğu tezi onların kuşaklararası dayanışma noktasında hâlâ büyük oranda yerine getirdikleri önemli görevi hepten yok saymaktan gelmektedir. Yaşlıların "buyurgan" olarak karikatürize edilmeleri de göç, kentleşme, yoksulluk, aile yapısının değişmesi, doğal ve biyolojik felaketlere rağmen yaşlının da sanki geçmişte olan ayrıcalığının hiç etkilenmediği ezberinden kaynaklanmaktadır. Özellikle üzerinde durulması gereken noktalardan birisi de yaşlının "cinsel sapık" olarak karikatürize edilmesidir. Bu tamamen cinsellik açısından da insanın biyolojik yaşlanmasını bilmemekten ileri gelmektedir. Y

aşlıların "teknoloji okur-yazarlığı”nın gençlere nazaran düşüklüğü ve yaşlının da artık "yaşlandığını kabul etmeme"si bilimsel bir gözlem sonucu olabilmektedir, ama buna rağmen bunu karikatürize etmek yaşlı ayrımcılığını beslemektedir. Diğer yaş grupları gibi yaşlının da toplumdan "sayg1 bekleme" hakk1 vardır, ancak bu hakkı sanki hakk1 olmayan bir şeyi istemişmiş gibi karikatürize etmek yaşçılıktır.

Son olarak, yaşlıyı "inatçı", "hilekâr", “eşini hor gören”, "cadı" ve "paspal” olarak karikatürize etmenin onlar hakkındaki ön yargıları beslemektedir. Kitle iletişim araçları tarafından öğretilmiş ezberlerin mikro düzeyde bireyin algısını nasıl yanlış yönde değiştirildiğinin göstergesidir. Bunlar tamamen atomu parçalamaktan zor algı operasyonlarıyla oluşturulmuş önyargılar olup, yaşlılık olgusunu çarpıtmaya yöneliktir. Ne yazık ki bu tür yaşlılıkla ilgili kuşaktan kuşağa aktarılan olumsuz önyargılar/sterotipler hep olagelmiştir (Angus ve Reeve, 2006).

Tablo 2. TV (Dizi ve Film), Reklam ve Kitapta (Roman, Hikâye ve Masal) Yaşlı Ayrıcalı̆̆l ve Ayrımcılı̆̆ı

\begin{tabular}{|c|c|c|}
\hline TV (Dizi ve Film) & Reklam & Kitap (Roman, Hikâye ve Masal) \\
\hline Yaşlı Ayrıcalığı & Yaşlı Ayrıcalığı & Yaşlı Ayrıcalığı \\
\hline $\begin{array}{l}\text { Fedakâr, adil, zengin, kültürlü, } \\
\text { dinç, genç ruhlu, sevgi dolu, sayg1 } \\
\text { gören, aile reisi... }\end{array}$ & $\begin{array}{l}\text { Sayg1 gören, kültürün taşıyıcısı, } \\
\text { neşeli, sağlıklı, aile büyüğü... }\end{array}$ & $\begin{array}{l}\text { Bilgili, tecrübeli, sözü dinlenilen, } \\
\text { iyi niyetli, yol gösterici, koruyucu, } \\
\text { tutumlu, evin reisi... }\end{array}$ \\
\hline Yaş & & \\
\hline $\begin{array}{l}\text { Aceze, nasihatçı, otoriter, gençliğe } \\
\text { özenen, duygusal, huysuz, }\end{array}$ & $\begin{array}{l}\text { Muhtaç, pasif, zayıf, otoriter, } \\
\text { tutucu, gençliğe yabanc1... }\end{array}$ & $\begin{array}{l}\text { Hasta, muhtaç, yalnız, terkedilmiş, } \\
\text { asabi, gençlik karşıtı... }\end{array}$ \\
\hline
\end{tabular}
şikâyetçi, hasta, çocuksu, inatçı, çatışmacı, çapkın...

Tablo 1'de açıklanan yaşlı ayrımcılığı göstergelerinin dişında Tablo 2'de öne çıkan yaşlı ayrımcılığı unsurları yukarıdaki değerlendirmeyle bir bütünlük oluşturması açısından şu şekilde analiz edilebilir.

Birincisi, Tablo 2'de TV (dizi ve film) kategorisinde Tablo 1'dekilerden farklı olan yaşlı ayrımcılığı göstergeleri "duygusal", "çocuksu", "gençliğe özenen" ve "nasihatçi” unsurlarıdır. Geriye kalan diğer unsurlar zaten karikatürlerde de vardırlar ve analize tabi tutulmuşlardır. Dolayısıyla yukarıda analiz edilmeyen unsurlar şu şekilde ele alınabilir. Yaşlıların "çocuksu" ve "duygusal" olduklarına dair toplumda önyargılar zaten mevcuttur. Yaş ilerledikçe onların 
tıpkı çocukluk dönemlerindeki gibi bakıma, ilgi ve alakaya ihtiyaç duydukları ve dolayısıyla bunlar yapılmadı̆̆ 1 vakit duygu dünyalarında birtakım şeylerin yaşandığı iddia edilebilmektedir, fakat bütün bunlara rağmen "yaşlılığın çocuksulaştırılması" ve yaşlıların "duygularının esiri”" olarak gösterilmeleri yaşcılığın bir sonucudur. Aynı mecralarda yaşlıların "nasihatçi" ve "gençliğe özenen" olarak gösterilmeleri de bununla bir tezat oluşturmaktadır. Örneğin, çocuksu gösterilen yaşlılar aynı zamanda nasıl nasihat verebilecek konumda da olabiliyorlar ki? Son olarak, yaşlıların "gençliğe özenen"ler şeklinde sunulmaları da bir tür yaşlı ayrımcılığıdır, çünkü yaşlıların gençlere özenmeleri, hep genç kalmak istemeleri olgusundan farklıdır. İlkinde kendini gençlikten aşağıda görme vardır, diğerinde ise yaşamlarındaki geride bırakılmış bir döneme özlem ve nostaljik duygular vardır.

İkincisi, Tablo 2'de şu ana kadar anlatıların dışında kaynak taramasının yanında 70 katılımcının izledikleri reklamlarda söyledikleri yaşlı ayrımcılığı göstergelerinden farklı olanlar, yaşlıların "tutucu" ve "gençliğe yabancı" olarak gösterilmeleridir. Yaş ilerledikçe insanların durulduğu ve muhafazakârlaştığı yönünde birtakım bilimsel çalışmalar vardır, ancak bunun "tutucu"luk olarak sunulması yaşlı ayrımcılığı bağlamında bir etiketlemedir. Yaşlıların "gençliğe yabancı"ymış gibi sunulmaları da kuşaklararası dayanışmayı yok saymaktır. Aile içinde tutun toplumun her alanında gençlerle kol kola gönüllülük çalışmaları yapan ve tecrübelerini gençlere aktarıp onların başarılı olmalarında rol oynayan yaşlılar vardır.

Son olarak, Tablo 2'de yaşlı ayrımcılığı bağlamında şu ana kadar değinmediğimiz kitap (roman, hikâye ve masal) kategorisinde göze çarpan yaşlıların "yalnız", "terkedilmiş" ve "asabi” olduklarıdır. Yaşlıların yalnızlığı veya sosyal izolasyonu toplumsal bir gerçektir, fakat yalnız yaşamak her zaman için terkedilmiş anlamına gelmemektedir, çünkü yaşlılar çoğu zaman çocuklarına yük olmamak ve bağımsız yaşamak için de yalnız kalmayı tercih etmektedirler. Dolayısıyla yaşlıyı "yalnız" ve "terkedilmiş" gösterme işinde de gizil yaşlı ayırımcılığı vardır. Yaşlıların "asabi" olarak sunulmasına gelince bırakın yaşlıları başka yaş kategorisinden birilerini de olsa "asabi” olarak göstermek bir etiketleme ve dolayısıyla açık bir yaşç1lıktır.

Tablo 2'de görüldüğü üzere, TV (dizi ve film), reklam ve kitap (roman, hikâye ve masal) kategorileri altında yaşlı ayrımcılığının yanı sıra yaşlı ayrıcalığına da yer verilmiştir.

Öncellikle TV (dizi ve film) kategorisindeki yaşlı ayrıcalığının unsurlarına bakarsak yaşlıların bu mecralarda "fedakâr", "adil”, "zengin", "kültürlü”, "dinç", "genç ruhlu", "sevgi dolu", "sayg1 gören", "aile reisi" şeklinde sunuldukları tespit edilmiştir. Bütün bunlar, Türkiye'de son zamanlara kadar reisinin bir yaşlı büyüğün olduğu geniş aile ile somutlaşan yaşlı ayrıcalığının varlığını gösteren unsurlardır. Hatta günümüzde bile modernleşme ile birlikte çekirdek aile özellikle kentlerde öne çıkmaya başlamışsa da bir yaşlı büyüğün aile reisi olduğu geniş aile çekirdek aileyle ilişkili bir şekilde varlığını sürdürmektedir (Keskin, 2016, s. 95). Yaşlının/aile reisinin sıfatları olarak görülebilecek diğer bütün unsurlar da gösteriyorlar ki yaşlı ayrıcalığı, yaşı ayrımcılığıyla eş zamanlı olarak TV (dizi ve film) kategorisinde varlığını sürdürmektedir.

Sonrasında reklam kategorisinde ise, TV (dizi ve film) için görülen üzerinde durduğumuz unsurların yanında farklı olan yaşlıların "kültürün taşıyıcı" olarak sunulmaları yaşlı ayrıcalığının sürdüğünün önemli bir delilidir. Yazılı kültürün yanında sözlü kültürün hâlâ varlığını sürdürdüğü Türkiye'de yeni kuşaklara bu kültürel aktarımı sağlayanların yaşlılar olmas1 sürpriz değildir.

Son kategori olan kitap (roman, hikâye ve masal) kısmında yukarıda analiz ettiğimiz unsurlara ek olarak yaşlıların, yaşlı ayrıcalığı bağlamında "bilgili", "tecrübeli", "sözü dinlenilen", "iyi niyetli", "yol gösterici", "koruyucu", "tutumlu", "evin reisi" olarak 
kahramanlaştırıldıkları görülmüştür. İşte bu, bilgili, deneyimli, koruyup kollayan, yol gösterici ve tutumlu olan yaşlıların tecrübesinden dün olduğu gibi bugün de Türkiye'de faydalanıldığını göstermektedir.

\section{Tartışma ve Sonuç}

Yaşlı ayrıcalığı ve ayrımcılığının her ülkede olduğu gibi Türkiye'de de farklı tezahürleri vardır. $\mathrm{Bu}$, yukarıda literatür taramasında görülmüş ve bulgularla da desteklenmiştir. Sınırlılıkları açısından söz konusu her iki alanda bir fizibilite çalışması olmasına rağmen araştırmada genel itibariyle şu sonuçlara ulaşılmıştır.

Birincisi, çoğu toplumda yaşlı ya yüceltilerek "ayrıcalıklı” bir konuma yerleştirilmektedir ya da hiç muhatap alınmayarak "ayrımcılığa" tabi tutulmaktadır. Daha önce gerontokrasiyle toplumun önderleri ve aile reisleri olarak her alanda ayrıcalıklı ve görünür kılınan yaşlılar, modernleşmeyle birlikte özellikle medyadaki sunumla artık "mizah malzemesi” yapılarak itibarsızlaştırılmaktadırlar. Tablo 1'de 37 karikatürde yaşlı ayrıcalığının hiçbir emaresine rastlanmayıp hepten yaşlı ayrımcılığının işlenmesi, toplumda yaşlılık algısının "şaka/mizah" yoluyla farklı bir yöne çekilmek istendiğine işaret etmektedir. Bir başka deyişle, yaşlıyı karikatürize ederek oluşturulmak istenen algının, asli yaşlılık olgusunun önüne geçirilmesi artık toplumda baş göstermiş yaşlı ayrımcılığını besleyecektir. İzlenen TV (dizi, film ve reklam) ve okunan kitap (roman, hikâye ve masal) kategorilerine dahi yansıyan yaşlı ayrımcılığı ifadeleri tehlikenin boyutunu gözler önüne sermektedir. Buna rağmen söz konusu kategorilerde yaşlı ayrıcalığına dair ifadelerin de olması, çalışmanın sadece bir fizibilite çalışması olması sınırlılığına rağmen, Türkiye'de yaşlı ayrımcılığını dengeleyici mekanizmaların da hâlâ devrede olduğunu göstermektedir.

İkincisi, sosyal içerme yaşlı ayrıcalığının, sosyal dışlanma ise yaşlı ayrımcılığının tezahürüdür. Yukarıdaki bulgularda yaşlıların "aile reisleri" olarak hâlâ "sözlerinin dinleniyor olması" kısmen de sosyal içermeye bağlı olarak toplumsal katılımlarını ifade etmektedir. Öte yandan "yalnız" ve "muhtaç" olarak sunulmaları, sosyal dışlanma nedeniyle bir izolasyonla karşıya kaldıklarını da ortaya koymaktadır. Yaşlıların sosyal içermeye ve dışlanmaya maruz kalmaları gerontoloji kuramlarındaki tartışmalara yansıyacak denli bariz bir hale gelmiştir. Mesela, yaşamdan geri çekilme kuramı ve etkinlik kuramı arasındaki süregelen tartışmalar bu bağlamda değerlendirilmektedir. Kısacası, yaşamdan geri çekilme kuramı, yaşların kendilerini hayattan geri çekmekle ancak huzura kavuşacakları varsayımına dayanmaktadır (Akçay, 2011). Oysa bu çoğu zaman onların toplumdan dışlanmalarının meşrulaştırılması anlamına gelmektedir. Etkinlik kuramı buna bir itiraz şeklinde gelişerek aksine yaşlıların ancak yaşam boyu aktif kalarak mutlu kalabileceklerini ispatlamaya çalışmaktadır (Şentürk, 2018). Lakin bu teori de bedende yaşın ilerlemesiyle gelen biyolojik zayıflamaları görmezden gelerek "süperyaşlılar" üreterek onları olduklarından farklı göstermekle diğer yaş gruplarından farklı bir ayırıma tabi tutmaktadır.

Yaşlının çevresiyle uyumu, onu hayata bağlayan etkenlerin başında gelmektedir. Bu nedenle, yaşlının "yerinde yaşlanma"sının önemine binaen bu yönde çalışmalar son zamanlarda artmaya başlamıştır, çünkü "yerinde yaşlanma" yaşlının yaşam kalitesini artırma, sosyal katılım sağlama ve sosyal ilişki kurma firsatı sunmaktadır (Kütmeç Yılmaz, 2020; Yalçınöz Baysal, Aktaş ve Bakan, 2020; Çiçek, Şahin ve Erkal, 2020; Özmete ve Dinç, 2020). Bu nedenledir ki yaş(11) dostu şehirler, mekân gerontolojisinin önemli konularından birini oluşturmuştur. Buradaki temel amaçlardan biri, yaşlı ayrımcılık pratiklerinin mekân ve soysal ilişkiler dolayımı ile azaltılmasını sağlamaktır. Çünkü sosyal ilişkiler beraberinde yardımlaşmayı ve 
kucaklaşmayı getirmektedir. Tersi ise zaten sosyal izolasyondur/soysal dışlanmadır. Sosyal dişlanmayla, sosyal uyumun tersine, yaşlı marjinalize edilmektedir ve böylece her türlü sosyal karar alma mekanizmalarının dışına itilmektedir (Witman, Iecovich ve Alfasi, 2014).

Son olarak, iyi niyetlilik yaşlı ayrıcalığı, istismar ise yaşlı ayrımcılığının tezahürüdür. Örneğin, bulgulardaki kitap (roman, hikâye ve masal) kategorisindeki "iyi niyetlilik" yaşlının ve de onunla irtibatlı herkeste olması gereken bir haslettir, ancak ne yazık ki yaşlı istismarı da bir tür yaşlı ayrımcılığ 1 olarak tezahür etmektedir. Yaşlı istismarı iki boyutludur. Bir boyutu yaşlının kendini ihmali, diğeri de toplumun onu istismarıdır. Yaşı istismarı her alanda yaşanabilmektedir. Özellikle yaşlıların güçsüzleşmeleri ve kimsesiz kalmaları durumunda cinsel, fiziksel, finansal açılardan istismara maruz kalmaktadırlar; sözlü saldırılarla psikolojik baskılara uğramaktadırlar.

Yaşlı ayrıcalığı, ayrıcalığı emekli maaşının düşük olmaması şartıyla erken emeklilik imkânı ve toplu taşıma araçlarında bedava ulaşım imkânını sağlamak ise pozitif ayrımcılık kabilenden bazı alanlarda meşru görülmektedir. Ancak yaşlı ayrımcılığı günümüzde toplumun her alanına yayılarak büyük bir sorun haline geldiği için hiçbir şekilde kabul edilmemektedir.

Yaşlılara ayrımcılık belirli bir topluma has değildir. Ne yazık ki artık küresel bir boyut kazanmıştır. Buna karşı çözüm bulunması adımları vardır, fakat bunlardan da bazılarının yaşlı ayrımcılığını tersinden beslediği görülmektedir. Örneğin, yaşlıların hep genç kalma isteği, "yaşlanmayı geciktirme ve hatta yok etme" iddiasına sahip "anti-ageing" ticari hareketiyle yaşlıların duyguları dahi sömürülmeye başlanmıştır. Dahası, "başarılı yaşlanma" adı altında yapılan organizasyonlarda yaşlıları tamamen bir "müşteri" olarak gören bir ekonomi sektörü oluşmuştur. Bu, tabii ki "anti-ageing" ve "başarılı yaşlanma"nın hiç iyi taraflarının olmadığı anlamına gelmemektedir. Burada önemli olan şey, bu tür akımların yaşlılığın biyolojik, fizyolojik ve psikolojik yönlerini tamamen es geçerek, "hep genç kalma"nın iksiri bulunmuşmuş gibi, bir yaklaşım sergilemelerinin de dolaylı yaşlı ayrımcılığı pratikleri olduklarıdır.

Medya aygıtları yaşlılara yer verseler de bunu daha çok onları mizah malzemesi yapma yoluyla bir ayrımcılığa tabi tutarak yapmaktadır. Örneğin, gelin-kaynana dayanışmasına yönelik bir yapıma pek rastlanmamaktadır. Tersine, gelin-kaynana (ç)atışmalarıyla yaşlılar özellikle "geçimsiz" kişiler olarak gösterilmektedir. Reklamlarda ise olumlu örnekler olmasına rağmen yaşlı bedenlerin de artık ticari reklamların bir ögesi haline getirilip metalaştırıldığı ve ancak öyle sunabildiği gözden kaçmamaktadır. $\mathrm{Bu}$ nedenle, netice itibariyle neresinden bakılırsa bakılsın yaşlı ayrımcılığı toplumun her alanına yayıldığı için önlenmesi gereken bir sorun olmuştur ve dolayısıyla yaşlı ayrıcalığı çalışmalarıyla da dengelenerek yapılacak yeni çalışmalarla her açıdan incelenmelidir.

\section{Etik Beyan}

“Türkiye'de Yaşlılık Algısl: Yaşlı Ayrıcalı̆̆l ve Ayrımcılığı Üzerine Bir İnceleme” başlıklı çalışmanın yazım sürecinde bilimsel, etik ve alıntı kurallarına uyulmuş; toplanan veriler üzerinde herhangi bir tahrifat yapılmamış ve bu çalışma herhangi başka bir akademik yayın ortamına değerlendirme için gönderilmemiştir.

\section{Kaynaklar}


Akçay, R. C. (2011). Yaşlılık: Kavramlar ve kuramlar. Kriter.

Akdemir, N., Çınar, F.İ., \& Görgülü, Ü. (2007). Yaşlılığın algılanması ve yaşlı ayrımcılığı. Turkish Journal of Geriatrics, 10(4), 215-222.

Angus, J., \& Reeve, P. (2006). Ageism: A threat to "Aging well" in the 21st Century. The Journal of Applied Gerontology, 25(2), 137-152. https://doi.org/10.1177/0733464805285745.

Avc1, A. (2003). Toplumsal eleştiri söylemi olarak mizah ve gülmece. Birikim Dergisi, (166), 80-96. https://birikimdergisi.com/dergiler/birikim/1/sayi-166-subat-2003-sayi-166-subat2003/2354/toplumsal-elestiri-soylemi-olarak-mizah-ve-gulmece/3891.

Band-Winterstein, T. (2015). Health care provision for older persons: The interplay between ageism and elder neglect. Journal of Applied Gerontology, 34(3), 113-127. https://doi.org/10.1177/0733464812475308.

Baybora, D. (2010). Çalışma yaşamında yaş ayrımcılığı ve Amerika Birleşik Devletleri'nde yaş ayrımcılığ1 düzenlemesi üzerine. Çalışma ve Toplum, (1), 33-57. https://www.acarindex.com/dosyalar/makale/acarindex-1423874021.pdf.

Butler, R. (1975). Why survive? Being old in America. Harper \& Row.

Buz, S. (2015). Yaşlı bireylere yönelik yaş ayrımcılığı. Elektronik Sosyal Bilimler Dergisi, 14(53), 268278. https://doi.org/10.17755/esosder.89453

Cherry, K.E., Allen, P.D., Danver, J.Y., \& Holand, K.R. Holland (2013). Contributions of social desirability to self-reported ageism. Journal of Applied Gerontology, 20(10), 1-22. https://doi.org/10.1177/0733464813484984.

Cowgill, D. O. (1974). Aging and modernization: A revision of the theory. J. F. Gubrium (Ed.), Communities and environmental policy içinde (ss. 124-146). Charles Thomas.

Cowgill, D. O., \& Holmes, L. (Eds.). (1972). Aging and modernization. Appleton Century-Crofts.

Çiçek, B., Şahin, H., \& Erkal, S. (2020) Determination of the opinions of individuals aged 65 and over on aging in place: the case of Ankara. Educational Gerontology, 46(4), 182-194. https://doi.org/10.1080/03601277.2020.1723213

Çilingiroğlu, N., \& Demirel, S. (2004). Yaşl1lık ve yaşlı ayrımcılığı. Türk Geriatri Dergisi, 7(4), 225230. http://geriatri.dergisi.org/uploads/pdf/pdf_TJG_239.pdf.

Ekinci, M. (2012). Üveys el-Karanî. E-Makâlât Mezhep Araştırmalart, 5(1), 113-118. Http://www.emakalat.com/en/download/article-file/63736.

Esendemir, Ş. (2015). Push factors of institutionalization of older adults in Turkey. LAP LAMBERT Academic Publishing.

Estes, C.L. (2001). Social policy \& aging. Sage Publication.

Fischer, D.H. (1978). Growing old in America. Oxford University Press.

Görgün Baran, A., (2012). Davranış bilimleri. Siyasal Kitabevi.

Kalınkara, V. (2011). Temel gerontoloji yaşlılık bilimi. Nobel Akademi Yayıncılık.

Karasoy, G. (2021). Sosyal bir sorun alanı olarak yaşlı yoksulluğunun incelenmesi. Manisa Celal Bayar Üniversitesi Sosyal Bilimler Dergisi, 19(3), 155-167. Doi: 10.18026/cbayarsos.889976.

Keskin, E.B. (2016). Kentleşme ve ailenin değişimi. Uludağ Yayınları.

Koçman, A. (2006). Yaşlılıkta bakıma muhtaçlık ve bakım güvencesi. Toplum ve Sosyal Hizmet, 17(2), 109-113. Https://dergipark.org.tr/tr/download/article-file/801023. 
Kütmeç Yılmaz, C. (2020). Yaşlı bireylerde yerinde yaşlanma ile başarılı yaşlanma ve yaşam doyumu arasındaki ilişkinin belirlenmesi. Sağlık ve Toplum, 20(3), 38-48.

Marshall, V.W (2007). Advancing sociology of ageism: A special section. Social Forces, 86(1), 257264.

Mchugh, K.E. (2003). Three faces of ageism: Society, image and place. Ageing and Society. 23(02), 165-185. https://doi.org/10.1017/S0144686X02001113.

Özbolat, A. (2016). Beşikten mezara: Yaşl11ı̆̆ın sosyolojisi ve din: Adana örneği. Çukurova Üniversitesi Illahiyat Fakültesi Dergisi, 16(2), 53-76. Https://dergipark.org.tr/en/download/articlefile/265113.

Özmete, E., \& Dinç, B. (2020). Yaşlıların "göç ve yerinde yaşlanma” bağlamında kentsel dönüşüm ile ilgili değerlendirmeleri. Sosyal Politika Çalışmaları Dergisi, 20(46), 197-234. https://doi.org/10.21560/spcd.v20i54504.660460.

Palmore, E. (1999). Ageism: Negative and positive. Springer Publishing Co.

Powell, J., \& Chen, S. (2017). The problem of biology and anti-aging: A critical commentary. Trends in Medicine, 17, 1-3.

Sönmez, V., \& Alacapınar, F. G. (2017). Örneklendirilmiş araştırma yöntemleri (5. Baskı). Anı.

Street, D. A. (2007). Sociological approaches to understanding age and aging. J. A Blackburn ve C. N. Dulmus (Eds.), Handbook of gerontology: Evidence-based approaches to theory, practice, and policy (143-168) içinde. John Wiley \& Sons, Inc.

Şentürk, Ü. (2018). Yaşlılık sosyolojisi: Yaşlılı̆̆ın toplumsal yörüngeleri. Dora.

TDK (2011). Türkçe sözlük. Türk Dil Kurumu Yayınları.

Witman, A., Iecovich, E., \& Alfasi, N. (2014). Ageism and social integration of older adults in their neighborhoods in Israel. The Gerontologist, 54(2), 177-189. https://doi.org/10.1093/geront/gnt008.

Yalçınöz Baysal, H., Aktaş, B., \& Bakan, A.B. (2020). An investigation of the relationship between ageing in place and successful ageing in elderly individuals. Psychogeriatrics, (20), 473479. https://doi.org/10.1111/psyg.12534. 